\title{
AYURVEDIC PERSPECTIVE OF PATHOGENESIS OF HYPERTENSION
}

\author{
ABHIJEET B. PATIL, MD Kayachikitsa. \\ Asst Professor, Dr. J. J. Magdum Ayurved Medical College, \\ Jaysingpur, Kolhapur, Maharashtra
}

Corresponding Author: Ph. No.: 9158129793 Email: cardiadenix@gmail.com

\section{ABSTRACT :}

Heart disease is now the world's leading causes of death, claiming 17.3 million lives each year. Latest statistics in India suggest that, there are roughly 30 million heart patients. Of the 30 million heart patients in India, 14 million reside in urba areas and 16 million in rural areas. The word HRIDAYA is made up of HRI- DA$Y A$. HRI means Aharan, physiologically it means Venous Return or Preload, DA means Danarthaka or the Stroke Volume i.e. After load and YA means Gatyarthaka i.e. Rhythmic Contractility of Myocardium or heart rate. Heart is a aerobic organ and seat for oja, indriya, sadhak pitta, atma, pranvayu, avalambak kapha, mana and vyanvayu. It is mulasthan for pranvaha and rasavahasrotas and due to rasa vikshepana karma it gets associated with udakvaha, raktavaha and all the srotas of the body. Today's day to day life full of Atyadhik lavana sevana, Amla katu aahar, Atyadhik Manshashan, Avyayama, Bhay, Shok, Chinta, Krodha which leads to heterogeneous disease called as hypertension. The various mode of
Sampraptis being involved are discussed below.

KEYWORDS : Hridaya, Ras rakta samhana, oja, lavana sevana, chinta, krodha, hypertension, samprapti.

\section{NTRODUCTION}

Hypertension is one of most common problem of present time. Especially in industrialised and developing countries like India.

Exercise, anxiety, fear, emotional disturbances are now part of today's day to day life is leading cause of transient elevation of blood pressure.

More than $95 \%$ of patients have no identifiable underlying cause of hypertension. They are said to be have Essential hypertension or Idiopathic hypertension. In $70 \%$ of those with essential hypertension seen with family inheritance where genetic factors are effective.

Hypertension increases risk of cardiovascular diseases. In India it causes $85 \%$ of cerebro vascular accidents in which mortality rate is quite high. It also 
leads to subsequent complications, hence hypertension is called also called as silent killer.

In spite of tremendous advancement of modern system of medicine i.e. antihypertensive agents till date an ideal drug which can control hypertension and is harmless also having rejuvenating effects is necessary to manage the highly prevailing disease. Ayurveda has described rational treatment where the medicine not only modifies disease but also limits subsequent complaints.

MATERIAL AND METHODS : Study of literature of ayurved samhita and modern medicine in reference with concept of hypertension and representing various modes of sampraptis.

MATERIALS : Charak Samhita , chakrapani tika, vidyotini tika, Harrison's internal medicine, web

\section{SAMPRAPTI:}

Samprati denotes various stages of disease progression. It gives idea about dosh dhatu samoorchana along which treatment should be done.

Essential hypertension is not explained in classical text of samhitas. But according to vyadhi lakshanas we can know its samprapti, which explained in anukta vyadhi concept of acharya charak ( $\mathrm{Su}$ )

Various samprapti can be explained according to aetiological factors were as follows:

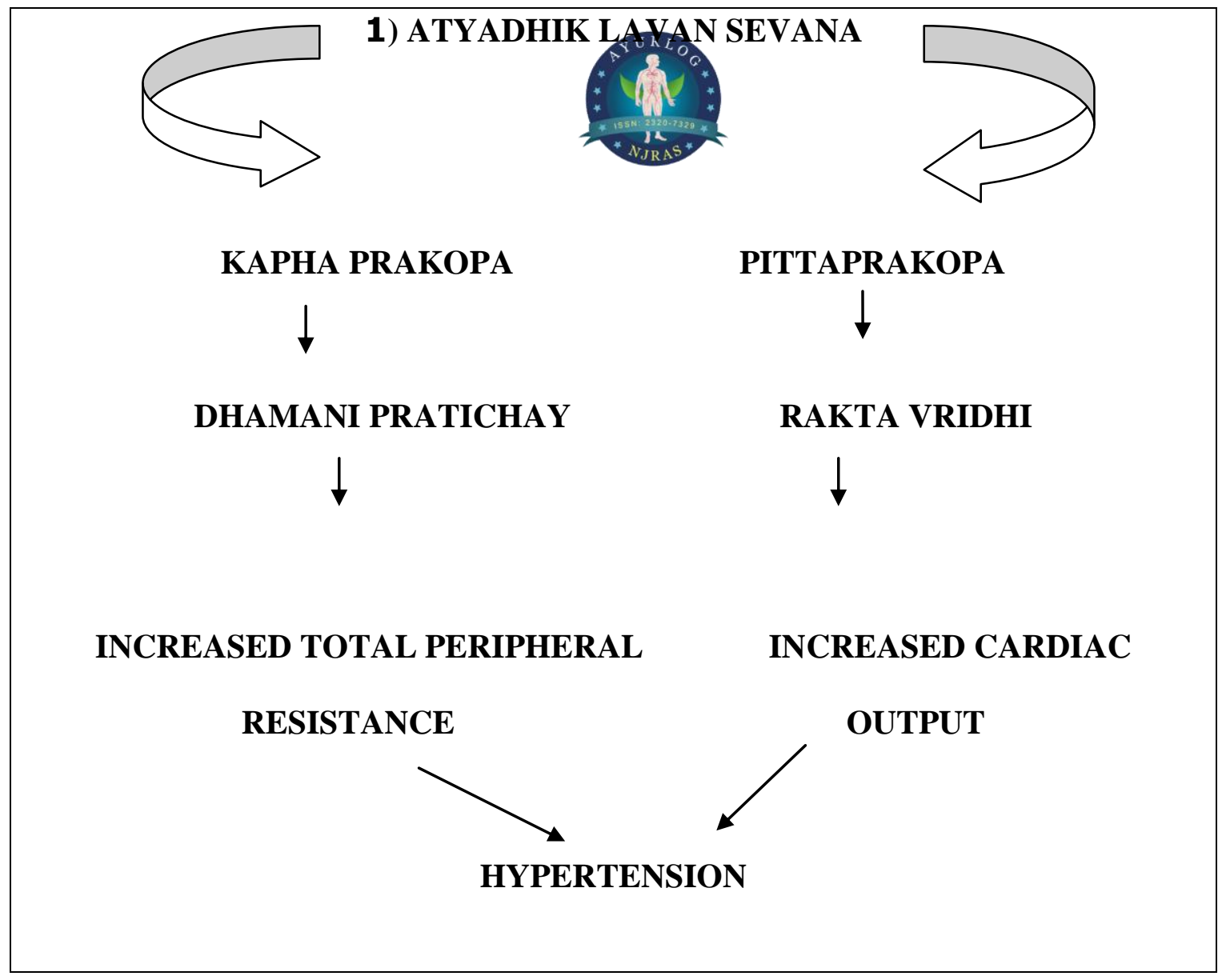


LAVAN RASATMAK AAHAR :

- Dietary salt i.e. lavan ras is now days become point of focus in aetiopathogenesis of hypertension.

- Lavan ras causes kapha prakopa as its saman gunatmak 1prabhav which leads to increase clotting tendencies of blood i.e. sang due to kapha. May lead to dhamanipratichay.
- Dhamanipraticahy obstructs blood flow and thus increases total peripheral resistance which then increases blood pressure.

- Lavan ras also vitiates pitta. In raktapitta chikitsa charak has explained pitta prakop causes swedan of dhatus increasing blood volume. It furthers increases cardiac output which results in to Hypertension

\section{2) AMLA KATU AAHAR, ATYADHIK MANSHASHAN}<smiles>C1CCC1</smiles>

\section{GURU SNIGDHA GUNATMAK}

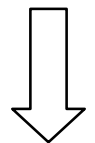

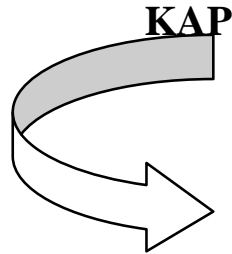

STROTORODHA

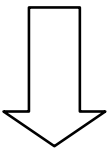

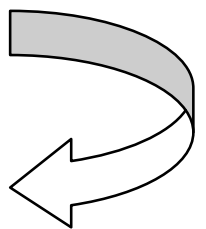

MEDOSANCHITI

\section{AVRITTA VYANA TOTAL PERIPHERAL RESISTANCE}<smiles>C1=CC=C1</smiles>

\section{HYPEERTENSION}

- Amla, katu gunatmak aahar vihar, mansashan are snigdha guru gunatmak in nature. It causes kapha prakopa. This kapha prakopa leads to excessive fat depoistion in body i.e. medosanchiti.

- Kapha prakopa causes medosanchti which obstruct normal blood flow in circulatory bed. It increases toatl peripheral resistance. For which heart has to increase force of contraction which inturns causes HTN.

- Kapha prakopa causes strotorodha which hampers ras rakta smvahana karma of vyana vayu and results into hypertension. 
3) AVYAYAMA

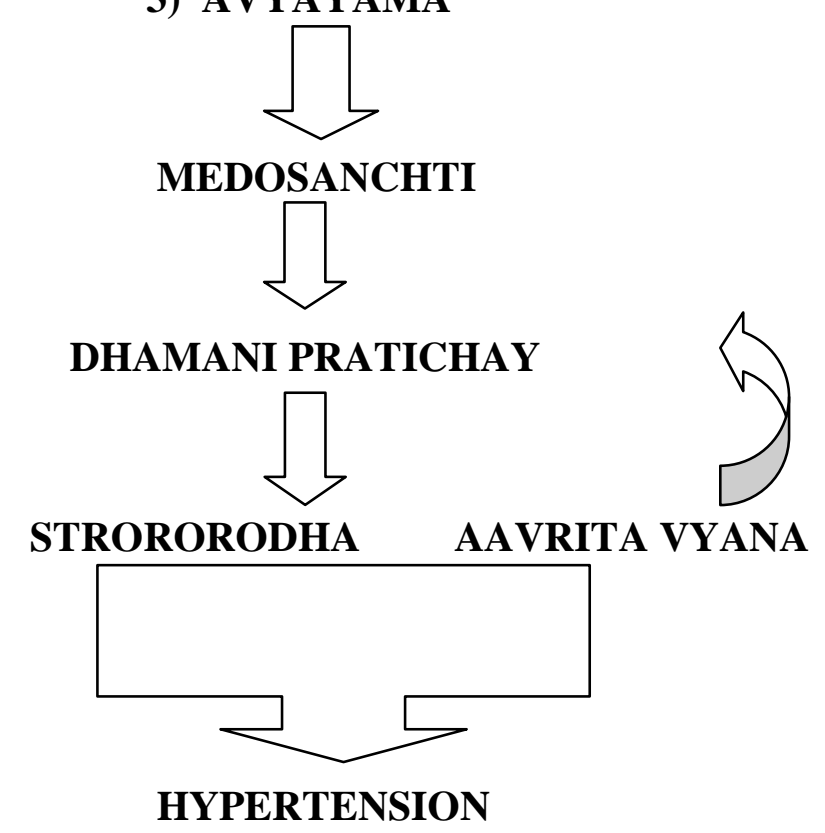

- Avyayam is very common in developing India. IT professionals where jobs are less exertional. Avyayam causes medosanchiti in body.

- Medosanchiti has hazardous ill effeccts as strotorodha and dhamanipratichay.

- Due to strotorodha or dhamanipratichay increases total peripheral resistance and therefore increases blood pressure. Also, dhamanipratichay may results into severe cardiac complications.

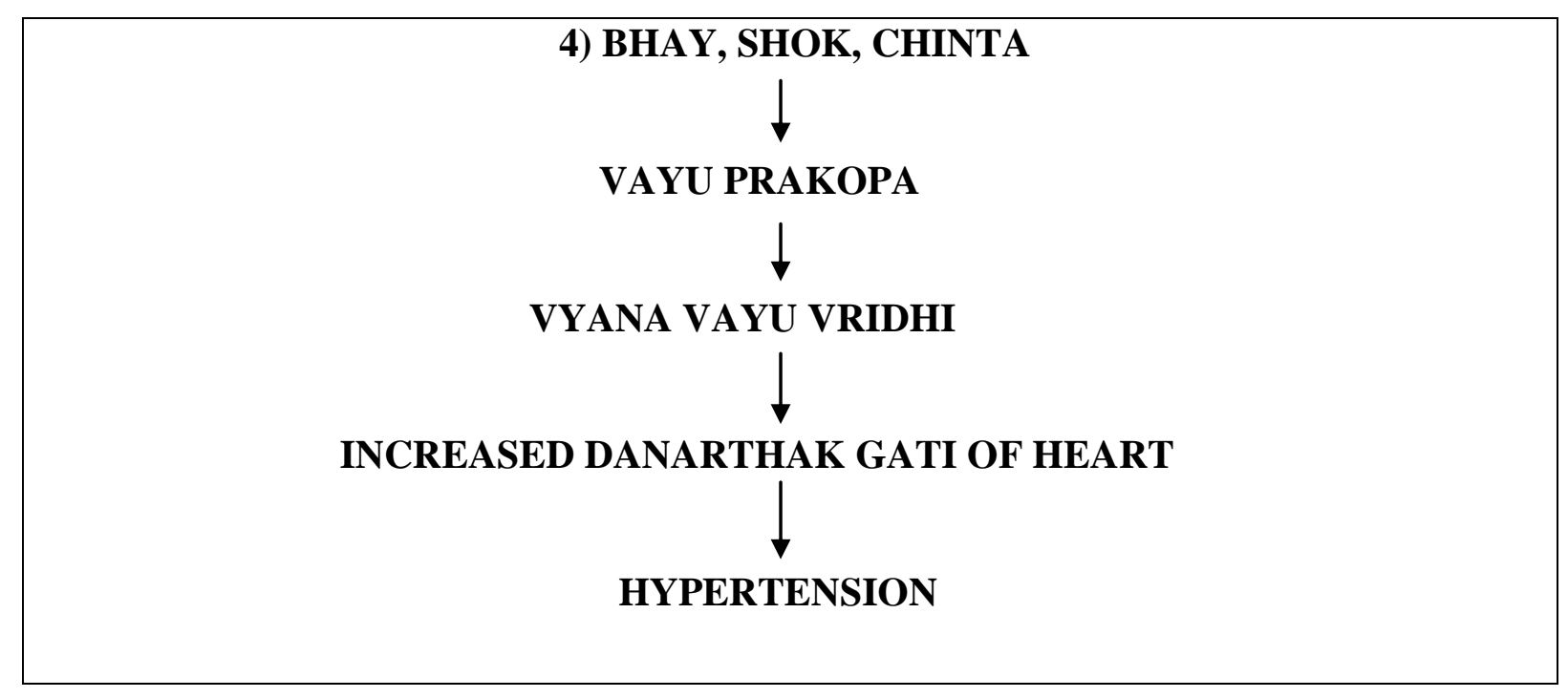

- Hridaya is seat of mansik bhavas. Any subject i.e. vishay dyan cannot be percieved without mind which itself explains its workout.
- Mansik bhava like bhay, shok, chinta, are main reason for vitiation of vata i.e. vaatprakopa. 
- Prakupit vata goes to hridaya there it vitiates vyana vayu causing vyana vayu vridhi.
- Vyana vayu is resposible for danarthak gati i.e. increased cardiac output which inturns causes hypertension

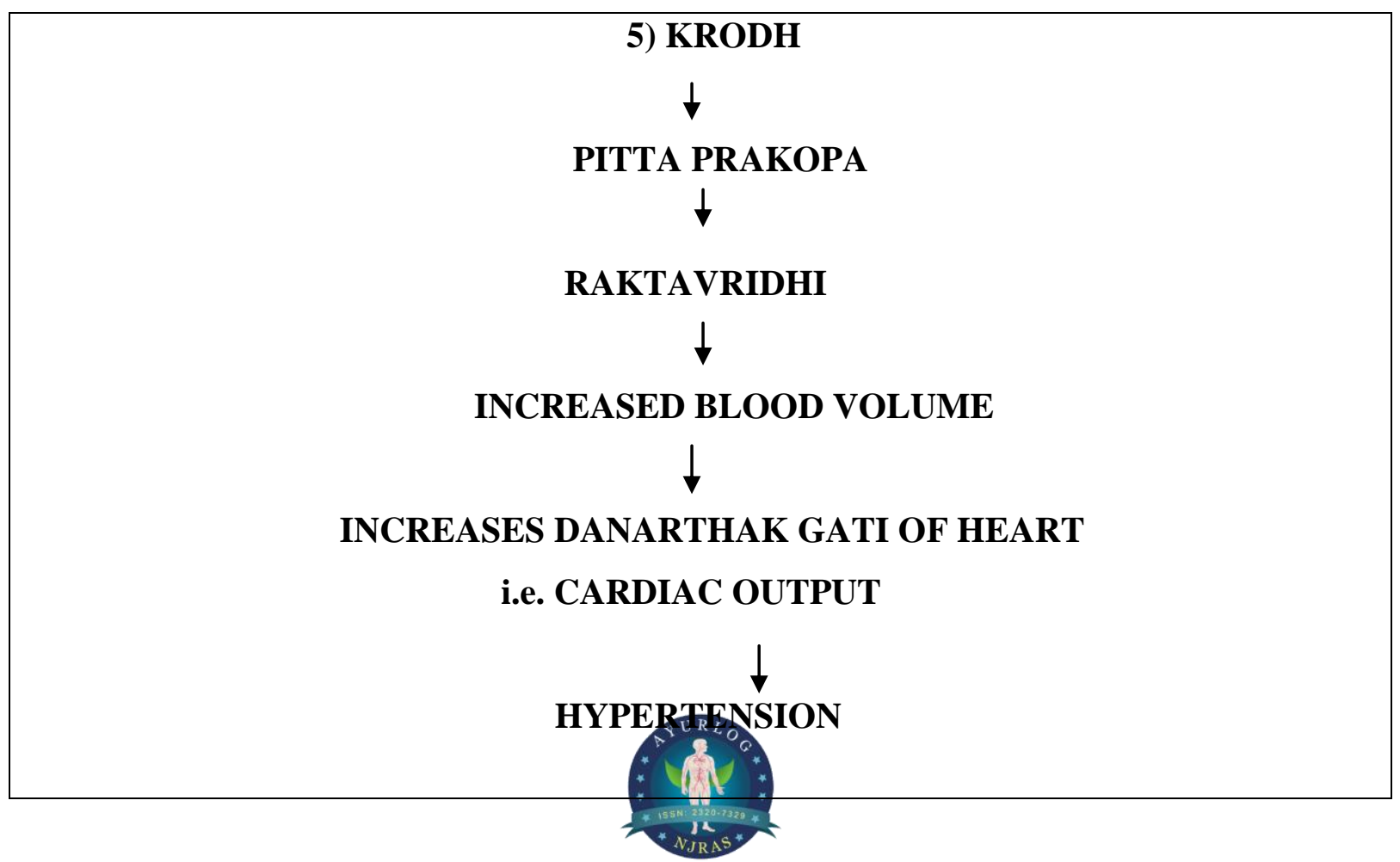

Krodah is one of dharnaiya vega which inturns causes pitta vridhi. Pitta vridhi is responsible for raktavridhi. This increases blood volume.

- It icreases danarthak gati i.e. cardiac output where it increases blood pressure.

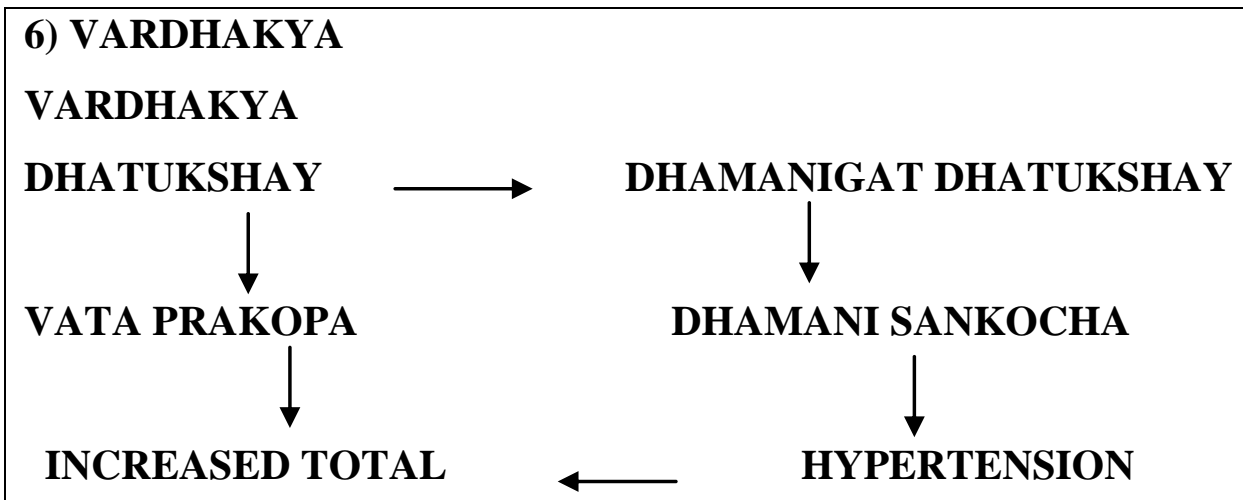

PERIPHERAL RESISTANCE 
- Vaardhakya is seat of agnimandya and dhatukshay.

- Dhaukshay leads to vaat prakopa.

- Prakupit vata vitiates vyana vayu and thereby causes increased cardiac ouput which results into HTN.

- Dhatukashay leading to dhamanisankocha which decreases lumen of blood vessels causing obstruction to blood flow.

- Hence, total peripheral resistance is increased after which heart has to workout more to counter. Thus it causes increase in blood pressure.

\section{SAMPRAPTI GHATAKA:}

Vata : Prana, Vyana, Apana

Pitta : Sadhaka

- Dosha : Kapha (Avalambaka)

- Dushya : Rasa, Rakta, Meda

- Agni : Jatharagni Mandhya Janita Aama, Rasa, Rakta Dhatvagni Janita Aama

- Srotasa : Rasavaha, Raktavaha, Pranavaha,

Manovaha

- Srotodusti Sanga, Vimarga Gamana

- Udbhavasthana Aamashaya

- Roga Marga : Kostha, Shakh

\section{DISCUSSION :}

Essential hypertension is one of most burning problem of modern era. WHO declared by 2017 India will be hub of hypertension. HTN is heterogenus disease involving multiple systems shows its deadly ill effects all over body. Based on concept of Anukta Vyadhi acharya charak had discussed that we should be able to name unknown disease according to its dosh-dushya sanghtana, poorvarup, lakshanas.

Atyadhika lavana sevana leads to increase in osmotic pressure and resultant kapha pitta prakopa causes increasing fluid volume and peripheral resistance responsible for hypertension.

Amla, katu ahar and atyadhik mansa aahar leads to increased medasanchiti which causes strotorodha and avruta vyan vayu, which increases peripheral resistance thus develops hypertension.

Iridaya being seat of mansik bhavas, the stress,shok,chinta,bhay leads to vyan vayu prakopa causing increase in heart rate and cardiac output which results into hypertension.

Vardhyakya denotes considerable dhatukshay causes dhamani gat dhatukshay and dhamani sankocha leads to development of peripheral vascular resistance results into hypertension.

\section{CONCLUSION:}

Hypertension is heterogeneous disease which is irrespective of age, sex, marital status and race. The samprapti involves vyan vayu prakopa due to sedentary and stress full life. Dhatukshay in vardhakya and kapha pitta samoorchana due to ati amla, lavana katu, mansa aahar, junk foods 
sevana leads to avrita vyan vayu leading to hypertension.

\section{REFERENCES:}

1. Chikitsa sthan Raktapita chikitsa adhyay 2, Dr Brahmanand Tripathi, Charak samhita, Choukhamba sur bharti, varanasi, Reprint 2008.

2. Chikitsa sthan Prameh chikitsa adhyay 6, Dr Brahmanand Tripathi, Charak samhita, Choukhamba sur bharti, varanasi, Reprint 2008.

3. Chikitsa sthan Trimarmiya chikitsa adhyay 26, Dr Brahmanand Tripathi, Charak samhita, Choukhamba sur bharti, varanasi, Reprint 2008.

4. Chikitsa sthan Raktapitta adhyay 2,Vd Satyanaryan Shastri, Charak samhita with Vidyotini tika, CHoukhamba academy,varanasi, reprint 2003.

5. Nidan sthan Raktapitta adhyay Acharya Trivikram Yadav, Charak samhita Chakrapani tika, choukhamba krishnadas academy, varanasi, reprint 2010.

6. Chikitsa sthan Raktapitta adhyay 2, Acharya Trivikram Yadav, Charak samhita Chakrapani tika, choukhamba krishnadas academy, varanasi, reprint 2010.

7. Chikitsa sthan Prameh-chikitsitam adhyay 6, Acharya Trivikram Yadav, Charak samhita Chakrapani tika, choukhamba krishnadas academy, varanasi, reprint 2010.

8. Chikitsa sthan Trimarmiya chikitisitam adhyay 26, Acharya Trivikram Yadav, Charak samhita Chakrapani tika, choukhamba krishnadas academy, varanasi, reprint 2010.

9. Chikitsa sthan Urustambh chikitsitam adhyay 27, Acharya Trivikram Yadav, Charak samhita Chakrapani tika, choukhamba krishnadas academy, varanasi, reprint 2010.

10. JNC Report $7^{\text {th }}$, Aug 2004, U.S. Department of health and human services, NIH Publication no 045230.

11. Diagnosis of cardiovascular system Vol II, Part 9, Harrison's Principles of internal medicine 17th Edition, MacGraw-Hill publication 2008.

12. Cardiology Vol II, Parts 12, API textbook of medicine 2015 10th edition, Jaypee brothers medical publications Delhi 2015.

Cite article:

AYURVEDIC PERSPECTIVE OF PATHOGENESIS OF HYPERTENSION

Abhijeet Patil

Ayurlog: National Journal of Research in Ayurved Science- 2018; (6)(6): 1-7 